\title{
The Comparative Effect of Content-based Language Teaching and Task-based Language Teaching on Iranian Pre-intermediate EFL Learners' Reading Skill
}

\author{
Ehsan Namaziandost \\ Department of English, Faculty of Humanities, Shahrekord Branch, Islamic Azad University, Shahrekord, Iran \\ Mehdi Nasri \\ Department of English, Faculty of Humanities, Shahrekord Branch, Islamic Azad University, Shahrekord, Iran \\ Sheida Ahmadi \\ State University of Malayer, Hamedan, Iran
}

\begin{abstract}
This study aimed to explore the effectiveness of TBLT and CBLT on Iranian Pre-intermediate EFL learners' reading skill. Forty pre-intermediate EFL learners were pretested and then homogenized and then divided to 2 classes, namely TBLT group and CBLT group. The CBLT group received reading instruction based on CBLT, while the RBLT group received reading instruction based on TBLT. After the treatment, both groups received a posttest. After analyzing the data through using paired and independent samples t-tests, it was shown that both groups (i.e., TBLT \& CBLT) progressed considerably with regard to their reading skill from the pretest to the posttest, with the task-based language teaching group outperformed the content-based language teaching group in the posttest. It can be deduced that both task-based language teaching and content-based language teaching methods are effectual in reading comprehension instruction to Iranian Preintermediate EFL learners, with TBLT method being more effective.
\end{abstract}

Index Terms - English as foreign language, content-based language teaching, task-based language teaching, reading comprehension

\section{INTRODUCTION}

In instructing and learning language numerous methodologies are connected all together that the point of the educating and learning can be accomplished in the classroom whether in formal and casual course. Methodologies have significant role in leading educating and figuring out how to enable instructor to structure how the classroom is intended to cause learners or student to be able to get what the instructor convey to them. Each methodology centers around who is the inside in instructing and learning process whether teacher centered or student centered (Namaziandost \& Ahmadi, 2019; Nasri, Biria, \& Karimi, 2018).

Nowadays, teaching and learning apply approaches that give students chance to do practices more than teacher does in the homeroom. Understudies have job much in learning process so the teacher as facilitator provide the guidance to do activities and control during the strategy. This student focused methodology has been connected since 1970s and all the more as of late as Pica expressed in Cook (2009, p. 75) "during the 1980s, Allwright (1984), Krashen and Terrell (1983), and Nunan (1989b) attracted consideration regarding student focused exercises and materials." Specialists in language learning offer regard for the exercises as well as the material given to the students so as to help the exercises are led in the learning procedure. Therefore, it is dire and gainful to bind language instructing techniques that are successful for various language abilities in EFL classes (Nasri \& Biria, 2017).

Content-Based Language Teaching (CBLT) and Task-Based Language Teaching (TBLT) are two of the most frequently inquired about, tentatively demonstrated compelling, in this manner most supported techniques in English as a Foreign Language (EFL) classes. However, their specific adequacy in EFL classes has been inadequately contemplated and accordingly stayed to be broke down (Hosseini, Nasri, \& Afghari, 2017). This study tries to explore the effectiveness of CBLT and TBLT in teaching reading to Iranian EFL learners and tries to find out their relative effectiveness. More specifically, the present study aims to answer the following three research questions:

\section{Research Questions}

RQ1. Does CBLT have any significant influence on Iranian Pre-intermediate EFL learners' reading skill?

RQ2. Does TBLT have any significant influence on Iranian Pre-intermediate EFL learners' reading skill? 
RQ3. Is there any significant difference between CBLT and TBLT in their effectiveness in teaching reading to Iranian Pre-intermediate EFL learners?

\section{LITERATURE REVIEW}

\section{A. $C B L T$}

CBLT is a vital approach in language instruction (Brinton, Snow, \& Wesche, 1989; Namaziandost, Hashemifardnia, \& Shafiee, 2019). It is an approach which combines language and content in teaching (Namaziandost \& Nasri, 2019; Snow, 2016). It falls under the broader rubric of communicative language teaching (CLT), along these lines it is student as opposed to instructor focused. In such homerooms, learners learn through doing and are effectively occupied with the learning procedure. According to Namaziandost, Nasri, and Rahimi Esfahani (2019), the coordination of language and substance educating is seen by the European Commission as "a brilliant method for gaining ground in an foreign language". CBLT adequately expands students' English language capability just as shows them the abilities essential for the accomplishment in their particular callings. Accordingly, it is thought to be a successful technique in showing ESP which additionally centers around substance explicit English learning (Azadi, Biria, \& Nasri, 2018).

Key features of content-based language teaching

There are two key highlights of content-based language encouraging which I will feature from the discussion above so as to translate the information underneath. To begin with, language work in CBLT instructional method is organized in the educating of subject substance. At the end of the day, CBLT isn't a submersion approach where the obtaining of language happens normally and can't be educated (Krashen, 1981). Or maybe, CBLT teaching method is educated by an information of etymology and a comprehension of language as perplexing open activity analyzable at the phonetic, syntactic, semantic and logical level. This information of language is worked into CBLT teaching method through a prospectus which spotlights on both language and substance points at the same time (Mohan, 1986; Mohan, Leung, \& Davison, 2001; Namaziandost, Abedi, \& Nasri, 2019). Second, CBLT perceives the requirement for educational and phonetic mediation in substance centered homerooms to improve the setting for second language students (Brinton, Snow, \& Wesche, 1989; Kessler, 1992; Namaziandost \& Shafiee, 2018). The need of foregrounding the metalinguistic work in the informative substance study halls is upheld by SLA investigate which demonstrates the staggering want is to make significance in such settings in this way diminishing the chance to remain back and center around structure.

\section{B. $T B L T$}

As another improvement of CLT, TBLT centers around requesting that learners do significant tasks utilizing the objective language, for example, asking the way, making a telephone call, going to a meeting and other data hole tasks. Tasks are the essential and center units in TBLT (Ellis, 2000). Tasks should be designed based on reliable criteria (Long, 2016; Namaziandost \& Nasri, 2019). As per Rod Ellis (2003), a task has four fundamental qualities. a. A task includes an essential spotlight on (sober minded) which means. b. A task has some sort of gap (information gap, reasoning gap, and opinion gap). c. The members pick the phonetic assets expected to finish the assignment. d. A task has a plainly characterized, non-phonetic result. These intellectually captivating errands can include understudies legitimately with the language being instructed and reflect genuine and deliberate utilization of language, consequently bringing about language-learning encounters that are pleasurable and viable (Namaziandost, Hashemifardnia, \& Shafiee, 2019). It has affirmed to be extremely useful in language instruction (Leaver \& Willis, 2004; Namaziandost \& Rahimi Esfahani, 2018). For teaching ESP, which focuses on the particular use of specialized English knowledge, TBLT is also supposed to be proper.

Task-based language teaching (TBLT) has turned into a critical point in the field of second language acquisitioning terms of encouraging procedure centered prospectuses and conceiving open errands to upgrade students' genuine language use through the rise of the informative language showing approach in the mid-1980s and much weight on students' informative capacities during the previous twenty years (Jeon \& Hahn, 2006; Namaziandost \& Shafiee, 2018). Little was expounded on errands before Prabhu's (1987) work. From that point forward, the arrangement of undertakings has turned out to be vital not just as a device of social occasion information from members yet in addition as an object of concentrate all by itself. The quantity of books distributed on this theme since 2000 (containing Bygate, Skehan, and Swain 2001; Ellis 2003; Nunan 2004; Leaver and Willis, 2005; Van den Branden, Bygate, and Norris 2009, among many others) obviously shows the increasing importance of tasks in research (Adams, 2009; Mirshekaran, Namaziandost, \& Nazari, 2018). Late research studies demonstrate three noteworthy qualities of undertaking based language training important to study hall practice: TBLT is in accordance with a student focused instructive way of thinking (Richards \& Rodgers, 2001; Ellis, 2003), it is comprised of explicit constituents, for example, objective, strategy, explicit result (Murphy, 2003; Nunan, 2004), and it supports content-situated significant exercises as opposed to semantic structures (Beglar \& Hunt, 2002; Littlewood, 2004; Namaziandost, Rahimi Esfahani, \& Hashemifardnia, 2018).

In all, it is reasonable to select CBLT and TBLT as the teaching methods to be studied. It's duly followed that their relative effectiveness should be made clear.

\section{Characteristics of TBLT}


In spite of the fact that there is a disparity of perspectives among the backers of task-based language educating in connection deeply standards of TBLT, Swan (2005) underlines that there is a general understanding among them on the attributes recorded beneath:

$>\quad$ Instructed language learning ought to predominantly contain characteristic $\neg$ or naturalistic language use, and the exercises are identified with significance as opposed to language.

$>\quad$ Instruction $\neg$ should bolster student centeredness as opposed to educator centeredness.

$>\quad$ Because absolutely naturalistic learning does not ordinarily offer ascent to target-like precision, commitment is fundamental to advance the disguise of formal phonetic components while keeping the apparent advantages of a characteristic methodology.

$>\quad$ This can be acknowledged best by offering open doors for spotlight on the structure, which will stand out for students to semantic parts as they rise by chance in exercises whose fundamental spotlight is on importance or correspondence.

$>\quad$ Communicative assignments are particularly appropriate $\neg$ devices for such a methodology.

$>\quad$ More formal pre-or post-task language study might be advantageous. This may make commitment to disguise by driving or boosting recognition with formal attributes during correspondence.

$>\quad$ Traditional methodologies are inefficient and unacceptable, $\neg$ particularly where they require aloof formal guidance and practice confined from informative work

\section{TBLT as a powerful approach for maximizing language learning and teaching}

Task-based methodology is an instructing approach utilizing undertakings as its principle educational apparatuses to structure language instructing. Its advocates set forward the perspective that task-based methodology is the reasonable upgrade of Communication Linguistics in that they have related standards in educating (Namaziandost, Sabzevari, \& Rasooyar, 2018). To show, the two of them concede that exercises for genuine correspondence are of most unmistakable quality in language learning; the two of them concede that using language to perform important errands can improve language learning; the two of them concede that the language which is significant to students can prepare for the learning procedure (Hashemifardnia, Namaziandost, \& Sepehri, 2018).Task-based methodology is an incredible and propelling learning strategy. It advances learning language information and preparing aptitudes during the time spent performing undertakings. Educators are the two teachers and aides. Likewise, students are the two collectors and fundamental operators. It is by means of TBLT that students will ace how to utilize their very own open capacities to move from L1 to the objective language. It displays an opportunity for them to adapt agreeably and actuates their likely capacities to utilize and manage the objective language in an expert manner (Lin, 2009). As Larsen-Freeman (2000) states, since language students endeavor to play out an undertaking, they have rich chance to associate with their companions. It is this association that is expected to ease language obtaining in that students are to attempt to fathom one another and to exhibit their own significance (Namaziandost \& Nasri, 2019). As a language instructor who shows English as an unknown language to Iranain EFL students, I utilize task-based way to deal with furnish students with a characteristic setting for language use, present a productive contribution of objective language for students, increment their capacity to convey successfully, and to boost their inspiration to the exercise (Abedi, Keshmirshekan, \& Namaziandost, 2019).

\section{Reading Comprehension}

Snow (2016) states that reading comprehension is the way toward developing the importance through collaboration and association with writing language. What's more, reading involves three components: 1) The reader who is doing the fathoming 2) The content that will be appreciated 3) The Activity where understanding is a section. The procedure this communication depends of the accessibility of nature of substance and methodologies in showing learning process. In view of the clarification above, perusing perception is the manner by which the reader comprehends the content. To comprehend the significance of the content, the reader must comprehend the importance of the words, sentences, passage just as sense relationship among the thoughts on the content. Hashemifardnia, Namaziandost, and Shafiee (2018) see the perusing perception as an intricate procedure that includes numerous associations among readers and what they think about the content (past learning, technique use) just as factors identified with the content itself, for example, enthusiasm for content and comprehension of content sorts. It implies that, perusing cognizance requires the reader ought to have learning to comprehend the content and how methodology in perusing to be connected which can assist the reader with figuring out the data from the content. In light of the clarification above, it tends to be presumed that perusing appreciation is an entangled procedure, which includes all part of human however and how the reader's that comprehension about the content about what they have perused with system, learning and give the content must fit with level of the reader.

\section{Methodology}

\section{A. Participants}

The participants of this study were 40 pre-intermediate Iranian EFL students from a private English language institute in Iran. They were selected from among 60 students based on their performance in English language proficiency test of Oxford Quick Placement Test (OQPT). They were female and their age ranges between 15 to 17 years old. They were randomly divided into two experimental groups; TBLT Group (n=20) and CBLT Group (n=20). 


\section{B. Instruments}

The first instrument which was utilized in the current study was the OQPT; it was used to make the students homogenous. It aided the researcher to determine his participants' proficiency level (i.e., elementary, pre-intermediate, intermediate, advanced). According to the results of the mentioned test, those students whose scores are between 28-33 are at pre-intermediate level and were chosen as the target population of the present research.

The second instrument which was used in the current study for gathering information was a researcher-made reading test which was used as both pre-test and posttest. The pretest and posttest were both composed of 4 reading passages, with 40 items and a total score of 20 points. In order to achieve high validity and reliability, the reading tasks were pilot-studied. The Parallel-Forms Reliability between the two test papers was 0.899, which is adequate enough. The reading course book used in the experimental intervention was ACTIVE Skills for Reading arrangement distributed by Heinle ELT. It is an amazing five-level perusing arrangement that improves understudies' perusing discernment and vocabulary capacities. It was formed by well-known master Neil J. Anderson, the new form of this top of the line arrangement uses an ACTIVE way to deal with arrangement with students become increasingly certain, free - and dynamic - readers. Dynamic Reading $\mathrm{A}=$ Actuate previous Knowledge $\mathrm{C}=$ Cultivate Vocabulary $\mathrm{T}=$ Think about Meaning I = Increase Reading Fluency V = Verify Strategies E = Evaluate movement. It was open to the understudies in the library of the establishment.

\section{Data Collection Procedure}

To do the present study, the researcher selected 40 homogenous (pre-intermediate) male students from among 60 students from a private English language institute in Iran, Iran. Then, the researcher divided the participants into two equal groups of 20; one TBLT group and one CBLT group. After that, the researcher administered a reading pre-test to evaluate the students' reading knowledge before practicing the treatment. In the next step, the TBLT group received reading comprehension instruction based on TBLT, while the CBLT group on CBLT. In CBLT group, the students read the texts and did related exercise. The researcher used pictures, audio clips, videos, PPT, etc. as much as possible, to motivate student's interest in the subject matter and facilitate students to engage in meaningful communication about the topics in English. Therefore, a majority of class time is spent in pair works and group discussions of the military matters and the issues that arise naturally from them. The classroom activities used include: brief quizzes; student brainstorming of some questions for group discussion; presentations made by the students to share information, and whole-group viewing key scenes for group discussion and analysis.

In TBLT group, the same reading texts were taught, but abiding by the principles of TBLT. More specifically, the students had to finish specially designed reading tasks, such as draw an information table after reading the text, perform a group discussion, carry out a class survey and write a survey report, etc. All of the tasks and the syllabuses were designed according to Ellis' 8 principles for designing lessons using task-based methodology. The whole treatment lasts 15 sessions of 60 minutes. After the experimental intervention, the students were post-tested. After collecting sufficient data through the aforesaid procedures, the data were analyzed by following the next section.

\section{Data Analysis Procedure}

In order to answer the research question of the study some steps were taken for data analysis. First, KolmogorovSmirnov (K-S) test was used in order to check the normality of the data. Then, Paired Samples Test was run to find out the effects of the treatment- TBLT vs. CBLT - on Iranian pre-intermediate EFL learners' reading skill.

\section{RESULTS AND DISCUSSION}

\section{A. Results of Normality Tests}

Before directing any investigations on the pretest, and posttest, it was important to check the typicality of the disseminations. Along these lines, Kolmogorov-Smirnov trial of typicality was kept running on the information acquired from the previously mentioned tests. The outcomes are appeared in Table 1:

TABLE 1.

NORMALITY TEST FOR THE SCORES OF THE PRETEST, AND POST-TEST

\begin{tabular}{cccc}
\hline & & Kolmogorov-Smirnov $^{\mathrm{a}}$ & \\
\cline { 2 - 4 } & Statistic & df & \\
\hline TBLT Group Pretest & .305 & 20 & .113 \\
\hline TBLT Group Posttest & .291 & 20 & .115 \\
\hline CBLT Group Pretest & .247 & 20 & .092 \\
\hline CBLT Group Posttest & .200 & 20 & .135 \\
\hline
\end{tabular}

The p esteems under the Sig. segment in Table 1 decide if the circulations were ordinary or not. A p esteem more noteworthy than .05 demonstrates an ordinary dispersion, while a p worth lower than .05 shows that the dissemination has not been typical. Since all the p esteems in Table 1 were bigger than .05 , it could be reasoned that the circulations of scores for the pretest, and posttest got students had been ordinary. It is subsequently protected to continue with 
parametric test (for example matched and free examples t tests for this situation) and make further correlations between the partaking gatherings.

\section{B. Pretest Results for the Two Groups}

The descriptive statistics for the performance of each of the two groups on the pretest are given in the following table.

TABLE 2.

DESCRIPTIVE STATISTICS ON THE (PRETEST OF BOTH GROUPS)

\begin{tabular}{ccccccc}
\hline & Groups & N & Mean & Std. Deviation & Std. Error Mean \\
\hline \multirow{2}{*}{ Pretest } & TBLT & 20 & 11.3500 & .98809 & .22094 \\
& CBLT & 20 & 11.1750 & 1.01664 & .22733 \\
\hline
\end{tabular}

So as to check whether there is any noteworthy contrast between the two gatherings at the start, an autonomous examples T-test was utilized. The aftereffects of T-test are exhibited in Table 3 beneath.

TABLE 3.

INDEPENDENT SAMPLES T-TEST FOR THE PRETEST SCORE OF THE BOTH GROUPS Levene's Test for Equality of Variances

\begin{tabular}{|c|c|c|c|c|c|c|}
\hline \multicolumn{7}{|c|}{ Levene's Test for Equality of Variances } \\
\hline & & & & \multicolumn{3}{|c|}{ t-test for Equality of Means } \\
\hline & & $\mathrm{F}$ & Sig. & $\mathrm{t}$ & $\mathrm{df}$ & Sig. (2-tailed) \\
\hline \multirow[t]{2}{*}{ Pretest } & Equal variances assumed & .004 & .948 & .552 & 38 & .584 \\
\hline & Equal variances not assumed & & & .552 & 37.969 & .584 \\
\hline
\end{tabular}

It is clear from Table 3 that the observed t-value is.552, but the p value is.584, which means that there wasn't any significant difference between the performances of the two groups at the beginning of the study and the two groups indeed belonged to the same population when the study started.

\section{Pretest and Posttest Results for the CBLT and TBLT Groups}

In order to find out if teaching reading through each of the two methodologies had any significant impact on the reading ability of the learners, the learners' scores on both pretest and posttest were compared for each group by using matched samples t-tests.

TABLE 4.

PAIRED SAMPles Statistics For TBLT AND CBLT PRETEST AND POSTTEST RESUlTS

\begin{tabular}{|c|c|c|c|c|c|}
\hline & & Mean & $\mathrm{N}$ & Std. Deviation & Std. Error Mean \\
\hline \multirow[t]{2}{*}{ Pair 1} & TBLT Post & 19.0250 & 20 & 1.15251 & .25771 \\
\hline & TBLT Pre & 11.3500 & 20 & .98809 & .22094 \\
\hline \multirow[t]{2}{*}{ Pair 2} & CBLT Post & 15.6000 & 20 & 1.14248 & .25547 \\
\hline & CBLT Pre & 11.1750 & 20 & 1.01664 & .22733 \\
\hline
\end{tabular}

The descriptive statistics for the performances of the TBLT group is given in Table 4. The mean score for the pretest is 11.3500 with a standard deviation of .98809 , while the mean score for the posttest with a standard deviation of 1.15251 is 19.0250. An observed difference can be seen between the performances in the posttest and pretest. Nevertheless, the question is whether such a difference is statistically significant or not.

Moreover, the descriptive statistics for the performances of the CBLT group is given in Table 4. The mean score for the pretest is 11.1750 with a standard deviation of 1.01664 , but the mean score for the posttest is 15.6000 with a standard deviation of 1.14248. Therefore, an observed difference between the performances of the CBLT group from the posttest to the pretest can be seen.

To find out whether the differences among these two mean scores in each group were statistically significant or not, the researcher had to examine the $p$ value under the Sig. column in the Table 5.

TABLE 5.

PAIRED SAMPLES T-TeSt (PRETEST AND POSTTEST OF Both CBLT AND TBLT GRoups

\begin{tabular}{cccccccc}
\hline & & Mean & Std. Deviation & Std. Error Mean & t & df & Sig. (2-tailed) \\
\hline Pair 1 & $\begin{array}{c}\text { TBLT Post } \\
- \text { TBLT Pre }\end{array}$ & 7.67500 & 1.79381 & .40111 & 19.134 & 19 & .000 \\
\hline Pair 2 & $\begin{array}{c}\text { CBLT Post } \\
- \text { CBLT Pre }\end{array}$ & 4.42500 & 1.59996 & .35776 & 12.369 & 19 & .000 \\
\hline
\end{tabular}

Table 5 reveals that there was a statistically significant difference between the pretest $(M=11.3500, S D=.98809)$ and posttest $(M=19.0250, S D=1.15251)$ scores of the TBLT group learners since the $p$ value under the $S i g$, (2-tailed) column was smaller than the significance level (i.e. .000<.05). This indicates that the treatment (using TBLT) was effective so far as the reading skills of the Iranian pre-intermediate EFL learners were concerned. Moreover, as Table 5 shows, that there was a statistically significant difference in the reading pretest and posttest scores of CBLT learners since the $\mathrm{p}$ esteem under the Sig. segment was not exactly the degree of essentialness (i.e., .000 < .05). Thus, it very 
well may be presumed that content-based language educating has been successful in showing perusing understanding to Iranian EFL students and the understudies' perusing capacity has improved fundamentally. So, the first research question is duly answered and Content-Based Language Teaching is effective in teaching reading to Iranian EFL learners. Furthermore, the second research question can also be answered and Task-Based Language Teaching is effective in teaching reading to Iranian EFL learners.

\section{Posttest Results for the CBLT and TBLT Groups}

Since the reading ability of both of the CBLT and TBLT groups has been improved, the remaining and main question of the current study is to check if there is any significant difference between CBLT and TBLT in their effectiveness in teaching reading to Iranian EFL learners. The descriptive statistics for the performances of the two groups on the posttest are shown in Table 6.

TABLE 6.

DESCRIPTIVE STATISTICS (POSTTEST OF Both GROUPS)

\begin{tabular}{cccccc}
\hline & Groups & $\mathrm{N}$ & Mean & Std. Deviation & Std. Error Mean \\
\hline \multirow{2}{*}{ Posttest } & TBLT & 20 & 19.0250 & 1.15251 & .25771 \\
& CBLT & 20 & 15.6000 & 1.14248 & .25547 \\
\hline
\end{tabular}

As shown in Table 6, the mean score for the TBLT Group on the posttest is 19.0250 and the mean score for the CBLT group is 15.6000. In this manner, there is a watched distinction between the exhibitions of the two gatherings on the posttest. Be that as it may, so as to check if such a distinction is measurably critical or not, a free examples t-test was utilized.

TABLE 7.

INDEPENDENT SAMPLES T-TEST For THE POSTTEST SCORE OF THE BOTH GROUPS

\begin{tabular}{|c|c|c|c|c|c|c|}
\hline & & \multicolumn{3}{|c|}{ Levene's Test for Equality of Variances } & & \\
\hline & & & & \multicolumn{3}{|c|}{ t-test for Equality of Means } \\
\hline & & $\mathrm{F}$ & Sig. & $\mathrm{t}$ & df & Sig. (2-tailed) \\
\hline \multirow[t]{2}{*}{ Posttest } & Equal variances assumed & .709 & .405 & 9.439 & 38 & .000 \\
\hline & Equal variances not assumed & & & 9.439 & 37.997 & .000 \\
\hline
\end{tabular}

As is clear from Table 7, the t-value for the posttest score of the TBLT group and the CBLT group is 9.139 (sig..000). Therefore, it can be concluded that there is significant difference between CBLT and TBLT in their effectiveness in teaching reading to Iranian EFL learners. Looking at the mean of both groups, it shows the mean score of TBLT group is higher than the mean score of CBLT group. All the more explicitly, task-based language instructing is more powerful than content-based language educating in instructing perusing to Iranian EFL students.

\section{CONCLUSION}

As it was seen over, the instructing strategy that spotlights on the language content and the one that focuses on utilizing language to complete important assignments are both powerful in showing English for explicit purposes. The reason is justifiable, for example the two training techniques and ESP are steady in their basic perspective on language: they treat language as an instrument in performing important and bona fide assignments, not a subject in its very own privilege (Faez, \& Tavakoli, 2018; Namaziandost, Rahimi Esfahani, \& Hashemifardnia, 2018). In the subsequent meeting, understudies for the most part gave positive criticism on two instructing techniques utilized. In the CBLT class, the substance, that is, the military issues, advances to them. In the TBLT class, the important errands draw in them. With respect to the predominance of TBLT over CBLT in showing ESP, the subsequent meeting likewise revealed some insight. The understudies in the TBLT bunch commonly mirrored that when completing the relegated undertakings, they needed to review and utilize all their past related language information and to ace new learning to effectively complete the assignment. In this procedure, their consideration was increasingly thought and the perusing abilities were all the more completely rehearsed. In addition, in CBLT the attention is on the substance and the understudies are generally worried about unimportant data or the topic and less worried about the language. Their past military learning can help them in perusing, regardless of whether they need related language information. For this situation, the learning of language is undermined. All things considered, in TBLT, both the learning and the control of language are considered. The undertakings are at the administration of the correspondence of importance through language (Namaziandost, Sabzevari, \& Hashemifardnia, 2018). In addition, the post-task period of TBLT is nothing not exactly a language-center stage during which the instructor deductively shows entangled formal parts of language that demonstrated risky to the students when playing out the assignment (Ellis, 2006; Namaziandost, Abdi Saray, \& Rahimi Esfahani, 2018; Nasri \& Biria, 2017). However, in CBLT, the focus on content renders a neglect of language. Therefore, for CBLT to be more effective, an extra conscious emphasis on language may do.

However, the present study is not without limitations. Among others, first, since Iranian EFL English reading is chosen as the teaching subject, the results cannot be readily and completely generalized to other subjects or to other English skills. In addition, only CBLT and TBLT were chosen as the teaching method to be researched and other, 
maybe more effective methods are left out intentionally. Therefore, more empirical studies, on other English subjects and on other teaching methods, are needed.

Task based learning has grown unmistakably over the most recent two decades and has remained a conceivably profitable methodology for various ESL/EFL instructors albeit a few analysts still look at the intensity of TBL (Büyükkarci, 2009; Namaziandost, Rahimi Esfahani, Nasri, and Mirshekaran, 2018; Azadi, Biria, and Nasri, 2018). Assignment based methodology, as Lin (2009) states, speaks to a popular idea in language educating. The motivation behind instructing isn't to help students in acquiring booked targets yet to give them the specific circumstance and conditions where language obtaining can occur. The educators' jobs have likewise been modified from teacher to establishers of study setting, colleagues, aides, and backers of the learning exercises. Students are the subjects in the study hall, which demonstrates that they are the key figures in the learning procedure. They are not void vessels to be filled by the instructors any more yet lights to be lit by means of offering suitable learning settings and tasks (Namaziandost, Hafezian, \& Shafiee, 2018; Hosseini, Nasri, \& Afghari, 2017).

The pedagogical benefits of task-based instructing of EFL are various. Undertaking based methodology has obstructed the separation among class and reality and has modified the negligence wherein educators completely confined conventional unknown dialect instructing from reality. Task-based methodology helps students in disguising language abilities in a characteristic manner and tells students the best way to deal with the issues that they experience, in actuality (Lin, 2009; Namaziandost, Rahimi Esfahani, and Ahmadi, 2019). At this crossroads, language instructors going for injecting task-based methodology into their language study halls should ascribe unmistakable quality to the accompanying focuses for the compelling usage of task-based teaching method (Ellis, 2009):

* The tasks must be adjusted to the etymological capability levels of the understudies (for example in the event that the understudies have confined capability, undertakings should initially be of the info providing instead of yield delivering type).

* Tasks ought to be trailed to give that they add to appropriate L2 use and amended inside the system of experience.

* For TBLT to work, instructors ought to have a clear understanding of what an undertaking is.

* Teachers and understudies ought to be made acquainted with the reason and rationale behind doing tasks (for example they ought to appreciate that errands add to coincidental learning of the thoughtful that will make ready for the advancement of their open aptitudes).

* Principally, the instructors participating in showing a task-based course should be occupied with the structure of the errand materials.

\section{REFERENCES}

[1] Abedi, P., Keshmirshekan, M. H., \& Namaziandost, E. (2019). The comparative effect of flipped classroom instruction versus traditional instruction on Iranian intermediate EFL learners' English composition writing. Journal of Applied Linguistics and Language Research, 6(4), 43-56.

[2] Adams, R. (2009). Recent publications on task-based language teaching: a review. International Journal of Applied Linguistics, 19(3), 339-355.

[3] Allwright. R.L. (1984), The Importance of Interaction in Classroom Language Learning. Applied Linguistics, 5, 156-71.

[4] Azadi, G., Biria, R., \& Nasri, M. (2018). Operationalising the Concept of Mediation in L2 Teacher Education. Journal of Language Teaching and Research, 9(1), 132-140.

[5] Beglar, D., \& Hunt, A. (2002). Implementing task-based language teaching. In J. Richards \& W. A. Renandya (Eds.), Methodology in language teaching: An anthology of current practice (pp. 96-106). Cambridge: Cambridge University Press.

[6] Brinton, D. M., Snow, M. A., \& Wesche, M. B. (1989). Content-based Second Language Instruction. New York: Newbury House.

[7] BüyükkarcÕ, K. (2009). A critical analysis of task-based learning. Kastamonu Journal of Education, 17(1), 313-320.

[8] Bygate, M., P. Skehan, \& Swain. M. (2001). Researching pedagogic tasks: second language learning, teaching, and testing. Harlow: Pearson Education.

[9] Cook, V. (Ed.) (2009). Contemporary Applied Linguistics Volume 1: Language Teaching and Learning. New York: Continuum International Publishing Group.

[10] Ellis, R. (2000). Task-based Research and Language Pedagogy. Language teaching research. Oxford: Oxford University Press.

[11] Ellis, R. (2003). Task-based Language Learning and Teaching. Oxford, New York: Oxford Applied Linguistics.

[12] Ellis, R. (2006). The Methodology of Task-Based Teaching. Journal of Foreign Language Education \& Research, 4, 79-101.

[13] Ellis, R. (2009). Task-based language teaching: sorting out the misunderstandings. International Journal of Applied Linguistics, 19(3), 221-246.

[14] Faez, F., \& Tavakoli, P. (2018). Task-Based Language Teaching. ELT Development Series. TESOL International Association, Alexandria, VA, USA, pp50. (In Press).

[15] Hashemifardnia, A., Namaziandost, E., \& Sepehri, M. (2018). The effectiveness of giving grade, corrective feedback, and corrective feedback-plus-giving grade on grammatical accuracy. International Journal of Research Studies in Language Learning, 8 (1), 15-27.

[16] Hashemifardnia, A., Namaziandost, E., Shafiee, S. (2018). The Effect of Implementing Flipped Classrooms on Iranian Junior High School Students' Reading Comprehension. Theory and Practice in Language Studies, 8(6), 665-673. 
[17] Hosseini, E. Z., Nasri, M., \& Afghari, A. (2017). Looking beyond teachers' classroom behavior: novice and experienced EFL teachers' practice of pedagogical Knowledge to Improve Learners' Motivational Strategies. Journal of Applied Linguistics and Language Research, 4(8), 183-200.

[18] Jeon, I. \& Hahn, J. (2006). Exploring EFL Teachers' Perceptions of Task-Based Language Teaching: A Case Study of Korean Secondary School Classroom Practice. Asian EFL Journal, 8(1), 123-143.

[19] Kessler, C. (Ed.). (1992). Cooperative language learning. Englewood Cliffs, NJ: Prentice Hall Regents.

[20] Krashen, S. \& Terrell, T. (1983). The Natural Approach: Language Acquisition in the Classroom. Oxford: Pergamon Press.

[21] Krashen, S. (1981). Second language acquisition and second language learning. Oxford: Pergamon Press.

[22] Larsen-Freeman, Diane. (2000). Techniques and Principles in Language Teaching. Oxford: Oxford University Press.

[23] Leaver, B. \& Willis, J. (2004). Task-Based Instruction in Foreign Language Education. Georgetown: Georgetown University Press.

[24] Lin, Z. (2009). Task-based Approach in Foreign Language Teaching in China: A Seminar Paper Research Presented to the Graduate Faculty, University of Wisconsin-Platteville. Available online at http://minds.wisconsin.edu/bitstream/handle/1793/34571/Zhu,\%20Lin.pdf.txt?sequence=3, accessed July 22, 2019.

[25] Littlewood, W. (2004). The Task Based Approach: Some Questions and Suggestions. ELT Journal 58(4), 319-326.

[26] Long, M. H. (2016). In defense of tasks and TBLT: Nonissues and real issues. Annual Review of Applied Linguistics, 36, 5-33.

[27] Mirshekaran, R., Namaziandost, E., \& Nazari, M. (2018). The Effects of Topic Interest and L2 Proficiency on Writing Skill among Iranian EFL Learners. Journal of Language Teaching and Research, 9(6), 1270-1276.

[28] Mohan, B. A. (1986). Language and content. Reading: Addison-Wesley Publishing Company.

[29] Mohan, B., Leung, C., \& Davison, C. (Eds.). (2001). English as a second language in the mainstream: Teaching, learning and identity. Harlow: Longman.

[30] Murphy, J. (2003). Task-based learning: the interaction between tasks and learners. ELT Journal, 57(4), 352-360.

[31] Namaziandost E., \& Nasri, M. (2019). A meticulous look at Long's (1981) interaction hypothesis: does it have any effect on speaking skill? Journal of Applied Linguistics and Language Research, 6(2), 218-230.

[32] Namaziandost E., \& Nasri, M. (2019). The impact of social media on EFL learners' speaking skill: a survey study involving EFL teachers and students. Journal of Applied Linguistics and Language Research, 6(3), 199-215.

[33] Namaziandost E., \& Shafiee, S. (2018). Gender Differences in the Use of Lexical Hedges in Academic Spoken Language among Iranian EFL Learners: A Comparative Study. International Journal of Research in English Education, 3(4), 64-80

[34] Namaziandost, E., \& Ahmadi, S. (2019). The Assessment of Oral Proficiency through Holistic and Analytic Techniques of Scoring: A Comparative Study. Applied Linguistics Research Journal, 3(2), 70-82.

[35] Namaziandost, E., \& Rahimi Esfahani, F., (2018). The Impact of Writing Practices on Enhancing Productive Skills Among PreIntermediate EFL Learners. AJTLHE, 10(1), 61-80.

[36] Namaziandost, E., Abdi Saray, A., \& Rahimi Esfahani, F. (2018). The effect of writing practice on improving speaking skill among pre-intermediate EFL learners. Theory and Practice in Language Studies, 8(1), 1690-1697. doi: http://dx.doi.org/10.17507/tpls.0812.16.

[37] Namaziandost, E., Abedi, P., \& Nasri, M. (2019). The Role of Gender in the Accuracy and Fluency of Iranian Upperintermediate EFL Learners' L2 Oral Productions. Journal of Applied Linguistics and Language Research, 6(3), 110-123.

[38] Namaziandost, E., Hafezian, M., \& Shafiee, S. (2018). Exploring the association among working memory, anxiety and Iranian EFL learners' listening comprehension. Asian-Pacific Journal of Second and Foreign Language Education, 3(20), 1-17. https://doi.org/10.1186/s40862-018-0061-3.

[39] Namaziandost, E., Hashemifardnia, A., \& Shafiee, S. (2019). The impact of opinion-gap, reasoning-gap, and information-gap tasks on EFL learners' speaking fluency. Cogent Social Sciences 5, 1630150 https://doi.org/10.1080/23311886.2019.1630150.

[40] Namaziandost, E., Nasri, M., \& Rahimi Esfahani, F. (2019). Pedagogical Efficacy of Experience-Based Learning (EBL) Strategies for Improving the Speaking Fluency of Upper-intermediate Male and Female Iranian EFL Students. International Journal of Research in English Education, 4(2), 29-41.

[41] Namaziandost, E., Rahimi Esfahani, F., \& Ahmadi, S. (2019). Varying levels of difficulty in L2 reading materials in the EFL classroom: Impact on comprehension and motivation. Cogent Education, 6, 1-9. https://doi.org/10.1080/2331186X.2019.1615740.

[42] Namaziandost, E., Rahimi Esfahani, F., \& Hashemifardnia, A. (2018). The Comparative Effect of Spacing Instruction and Massed Instruction on Intermediate EFL Learners' Reading Comprehension. SAGE Open, 1-8. https://doi.org/10.1177/215824401881102.

[43] Namaziandost, E., Rahimi Esfahani, F., \& Hashemifardnia, A. (2018). The Impact of Using Authentic Videos on Prosodic Ability among Foreign Language Learners. International Journal of Instruction, 11(4), 375-390.

[44] Namaziandost, E., Rahimi Esfahani, F., Nasri, M., \& Mirshekaran, R. (2018). The Effect of Gallery Walk Technique on Preintermediate EFL Learners' Speaking Skill. Language Teaching Research Quarterly, 8, 1-15.

[45] Namaziandost, E., Sabzevari, A. \& Rasooyar, H. (2018). Andragogically Oriented Teaching Method versus Pedagogically Oriented Teaching Method to Improve General English Achievement: A Comparative Study. International Journal of English Language \& Translation Studies, 6(2). 81-89.

[46] Namaziandost, E., Sabzevari, A., \& Hashemifardnia, A. (2018). The effect of cultural materials on listening comprehension among Iranian upper-intermediate EFL learners: In reference to gender. Cogent Education, 5 (1), 1-27.

[47] Nasri, M. \& Biria, R. (2017). Integrating multiple and focused strategies for improving reading comprehension and 12 lexical development of Iranian intermediate EFL learners. International Journal of Applied Linguistics \& English Literature, 6(1), 311-321.

[48] Nasri, M., Biria, R., \& Karimi, M. (2018). Projecting Gender Identity in Argumentative Written Discourse. International Journal of Applied Linguistics \& English Literature, 7(3), 201-205.

[49] Nunan, D. (1989b). Designing Tasks for the Communicative Classroom. Cambridge, Cambridge University Press.

[50] Nunan, D. (2004). Task-based language teaching. Cambridge: Cambridge University Press. 
[51] Prabhu, N. (1987). Second language pedagogy. Oxford: Oxford University Press.

[52] Richards, J. C., \& Rodgers, T. S. (2001). Approaches and Methods in Language Teaching. Cambridge: Cambridge University Press.

[53] Snow, M. A. (2016). Content-based language teaching and academic language development. Handbook of research in second language teaching and learning, 3, 159-166.

[54] Van den Branden, K., M. Bygate, \& Norris, J. (2009). Task-based language teaching: issues, research and practice. Amsterdam: Benjamins.
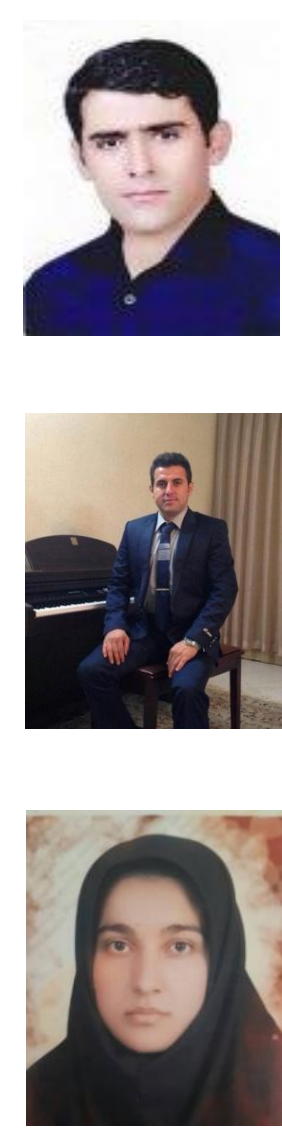

Ehsan Namaziandost was born in Shiraz Province of Iran in 1985. He holds an MA degree in TEFL from Islamic Azad University of Ahvaz. Now, he is Ph.D. candidate of TEFL at Islamic Azad University, Shahrekord, Iran. His main interests of research are second language acquisition, EFL teaching and testing, teaching language skills, and language learning strategies. His research papers and articles have been published by different international journals.

Mehdi Nasri was born in Isfahan, Iran. He holds a master's degree in TEFL from Islamic Azad University of Isfahan (Khorasgan). He is currently studying PhD in TEFL at Islamic Azad University of Shahrekord, Iran. He published some articles in different international journals and presented some ones in national conferences in Iran. His areas of interest are second language vocabulary learning and teaching, pragmatics, and reading comprehension.

Sheida Ahmadi was born in Tehran province of Iran in 1989. She holds a BA degree in English literature from State University of Malayer. She holds TESOl certificate from ITTI of New York. Her main interests of research are literature, teaching methods and language learning methods. Her research papers have been published by various international journals. 